\title{
The trajectory of the ability to innovate and the financial performance of the Brazilian industry
}

\author{
David Ferreira Lopes Santos ${ }^{\mathrm{a}, *}$, Leonardo Fernando Cruz Basso ${ }^{\mathrm{b}}$, Herbert Kimura ${ }^{\mathrm{c}}$ \\ a São Paulo State University (Unesp), School of Agricultural and Veterinarian Sciences, Jaboticabal, SP CEP 14.884-990, Brazil \\ b Mackenzie Presbyterian University, School of Applied Social Sciences, Sao Paulo, SP CEP 01302-907, Brazil \\ c University of Brasilia, School of Business, Accounting and Economics, Brasilia, DF CEP 70910-900, Brazil
}

\section{A R T I C L E I N F O}

\section{Keywords:}

Innovative capacity

Business competitiveness

Technological strategies

Emerging markets

Profitability

JEL classification:

L60

M21

O14

$\mathrm{O} 25$

O32

O33

\begin{abstract}
A B S T R A C T
This research analyzes the cumulative trajectory of Brazilian industry's ability to innovate and the impact of this resource on firms' financial performance. From a broad base of data taken at the firm level, a cross-sectional analysis and a longitudinal analysis were combined, through structural equation modelling, in the construction of the trajectory of resource innovation with the combined use of the following techniques: a multilevel model, latent trajectory analysis, and an autoregressive model. The empirical model shows that the ability to innovate consists of factors that are associated with internal, external, and human resources. The influence on financial performance is positive and significant when the analysis involves the long term. The autoregressive effect of the ability to innovate in time is not significant, suggesting that the innovation process is cumulative, interactive, and nonlinear. These results are relevant to emerging countries that require continued public policies and a greater intensity of business investment in the innovation process, aiming at the longevity of companies.
\end{abstract}

\section{Introduction}

Recent studies in innovation have sought to evaluate the cumulative trajectory of this organizational ability, whose bases turn towards the construction of technological paradigms, regimes, and standards (Castellacci, 2008; Figueiredo, 2010; Forés and Camisón, 2016; Sundbo and Gallouj, 2000).

In parallel to academic studies, analyses by market professionals and public managers focus on understanding how to foster and develop strategies that are oriented towards innovation, whose results contribute to the growth of companies and the development of countries (Damanpour et al., 2009; Hu, 2014, 2008; Kostopoulos et al., 2011; Lancker et al., 2016; Samara et al., 2012). However, as a result of its analytical complexity and its evolutionary nature as a process of knowledge accumulation and refinement, managing the ability to innovate is presented as one of the main challenges of organizational studies (Bessant, 2008; Cantwell and Fai, 1999; Dewangan and Godse, 2014; François et al., 2002; Kash and Rycroft, 2002; Olaru and Purchase, 2015; Rousseau et al., 2016; Silverberg and Verspagen,
2005).

The difficulty in modelling innovation as an organizational resource is expressed in the controversial results regarding its influence on the business and economic performance of firms (Cozzarin, 2004; Gunday et al., 2011; Jiménez-Jiménez and Sanz-Valle, 2011; Kim et al., 2016; Liao and Rice, 2010; Lööf and Heshmati, 2006, 2002; Prajogo, 2016).

More specifically, this scenario is relevant to emerging markets, whose insertion into global value chains depends on the degree of innovation and competitiveness of their companies, which brings with them institutional, environmental, and social demands that must be overcome (Castellacci and Natera, 2016; Paunov, 2012; Wu et al., 2016; Xie et al., 2016).

As one of the major emerging economies, in real terms, Brazil experienced an increase of $135 \%$ in investments in innovation between 2000 and 2013 (MCTI, 2016). In 2013, the expenditure on science, technology, and innovation was $1.24 \%$ of the gross domestic product (GDP) compared to an average of $1.9 \%$ for the top 40 countries with spending on innovation (UNDP, 2013). However, investments in innovation have not yet had a significant impact on the country. From

\footnotetext{
This document was a collaborative effort

t5 The authors gratefully acknowledge support from FAPESP (2013/12483-6), CAPES (Coordination for the Improvement of Higher Education Personnel) (20132053/ 33024014019P9), CNPq (National Council for Scientific and Technological Development) (443450/2014-5 and 310666/2016-3), and MackPesquisa (1562 NUCOI-FMP-030/2013).

* Corresponding author.

E-mail addresses: david.lopes@fcav.unesp.br (D.F.L. Santos), leonardofernando.basso@mackenzie.br (L.F.C. Basso), herbertkimura@unb.br (H. Kimura).
} 
2000 to 2012, for example, Brazil ranked only 70th in the Global Innovation Index 2015 (WIPO, 2015) and 74th in the Global Competitiveness Index (84th in the Innovation sub-item) (WEF, 2015), with a participation in international trade of only $1.22 \%$ in 2015 (WTO, 2015).

Given the need to analyze investments in the formation of the ability to innovate with the financial performance of companies in emerging economies, the following question motivates this study: How does the cumulative process of the ability to innovate influence the financial performance of Brazilian industrial companies?

Despite the limitations of research on this subject for the country (de Guimarães et al., 2016; Figueiredo, 2010; Santos et al., 2014), the Brazilian case can serve as a benchmark for other emerging countries, notably in Latin America, which demand higher investments in innovation to increase their competitiveness and economic development.

The specific condition of the Brazilian case, which may serve as a comparison for other emerging countries, has been characterized by: low intensity of business investments in R \& D (Cyrino et al., 2017), emphasis on directing investments to acquire machinery and equipment (Frank et al., 2016); lack of insertion of researchers, with master and doctorate degrees, in companies (Santos et al., 2014); little interaction between companies and universities and research institutes to generate innovation (de Moraes Silva et al., 2017). As the largest volume of expenditures on science, technology and innovation conducted by the country comes from the government and the interaction among triple helix agents (university, private sector and government) is limited, the aggregate results of innovation are modest (Cyrino et al., 2017). This environment may be similar to the context of many developing countries, which strive to get a competitive advantage from innovation.

The differences in the technological trajectories of each country or sector are viewed as one of the variables that explain the heterogeneity of the results of innovation, even among developed countries (Atalay et al., 2013; Castellacci and Natera, 2016; Jackson et al., 2016; Samara et al., 2012; Wu et al., 2016). However, there is still no empirical model that shows the cumulative process of innovation and the effects on financial performance (Liao and Rice, 2010; Olaru and Purchase, 2015).

Thus, with the aim of analyzing the cumulative trajectory of innovation and its impact on financial performance, this study proposes an exploratory model of the cumulative process of business innovation based on investments in innovation by Brazilian industry between 2000 and 2011 .

This article is organized as follows. The next section provides the theoretical foundations that justify the model structure and allow the results to be discussed. The third section presents the survey and construction process of the variables. The fourth section presents the analysis of the results, comparing them with the literature. Finally, the fifth section discusses the implications of the study for the theory of innovation and the development of public policies and business strategies.

\section{Theoretical framework}

The trajectory of innovation was formalized by Pavitt (1984), who showed differences in innovation investments and in innovation results among different sectors. The understanding of the differences in efforts and innovation results for each sector brought new prospects for the economic evaluation of innovation. Several quantitative studies whose data for analysis are aggregated by countries have been developed (Castellacci and Natera, 2016; Hatzikian, 2013; Hinloopen, 2003; Kirner et al., 2009; Solow, 1957).

The heterogeneous results confirm the difficulties in relating innovation investments to financial performance (Castellacci, 2008; Kleinschmidt, 1991; Liao and Rice, 2010; Santos et al., 2014). Crossan and Apaydin (2009) explain these differences by means of a framework that is divided into the determinants and the dimensions of innovation, with the determinants being distributed into group, organizational, and process levels and dimensions being stratified into process and results.
The methodological limitation in understanding the extent of the innovation process and the differences in its results in terms of sectorial characteristics is one of the current challenges of this area of knowledge (Atalay et al., 2013; Ryu and Lee, 2016). For instance, Weber and Schaper-Rinkel (2017) investigate quality innovation and performance in Swiss hospitals, Wang et al. (2015) analyze open innovation and performance in high tech companies.

The ability to innovate is an organizational resource that is continuous and non-discrete in nature; moreover, it has cumulative characteristics because its formation requires the development of knowledge in an interactive and recursive manner and is dependent on the social networks in which each firm is inserted (Dewangan and Godse, 2014; Figueiredo, 2010; Hatzikian, 2013; Kash and Rycroft, 2002; Lancker et al., 2016; Sundbo and Gallouj, 2000). Thus, there is a learning curve in the innovation process, which means that the results of this resource are best observed in the financial performance of companies (Cimoli and Dosi, 1995; Linton and Walsh, 2004; Teece, 2010; Velu, 2015).

The formation of the ability to innovate requires different types of investments (machinery, knowledge, people, materials, etc.) (Figueiredo, 2010; Urgal et al., 2011); manifests itself at all levels of the organization (strategic, tactical, and operational) (Teece, 2010); has results that are expressed in different ways (financial, market, operational) (Dewangan and Godse, 2014) and that can be compared in different ways (business, market, country, world) (Crossan and Apaydin, 2009); and must be analyzed considering the time variable, given that there is a cumulative factor of innovation efforts (Cantwell and Fai, 1999).

Internal research and development (R \& D) is the classic variable for measuring investments in innovation and a source of mandatory ability to innovate for companies that take offensive and defensive strategies of innovation (Baumann and Kritikos, 2016; Bäck and Kohtamäki, 2015; Colombo and Rabbiosi, 2014; Freeman and Soete, 1997; Howell, 2016; Hung and Chou, 2013; Kim et al., 2016). However, the ability to innovate is not restricted to these investments (Hatzikian, 2013; Lööf and Heshmati, 2006).

A second variable that is widely used to measure innovation is human capital, which is scaled in different ways (e.g., the number of engineers and/or technicians, length of experience, the institutional education level (doctorate, master's degree, bachelor's degree), the number of people dedicated to R \& D) (Hatzikian, 2013; Kim et al., 2016; Lööf and Heshmati, 2006).

Innovation, as an intangible resource, comprised by different internal and external sources to the organization, as well as, a result of a cumulative process of knowledge, allows the study of the different strategies and results, since the activities that constitute innovation are heterogeneous and exploited differently by firms (Tavassoli and Karlsson, 2015).

In this context, companies present different levels of innovation, reflecting their absorptive capacity and the persistence of innovation results, e.g., Bartoloni and Baussola (2017) and Maslach (2015). These concepts have been explored in the recent literature, and one of the central axes is the cumulative process of knowledge and learning from internal and external sources that provide better innovation and entrepreneurial performance (Lewin et al., 2011; Rangus and Slavec, 2017; Tavassoli and Karlsson, 2015; Tsai, 2001).

Our study shows that linking innovation with the financial performance of companies requires the need to understand innovation as an organizational resource that brings together tangible and intangible elements, internal and external, to companies. This argument is compatible with other studies (Lichtenthaler, 2016; Wang et al., 2017). However, differently from the studied literature, we present the capability to innovate as a cumulative resource, i.e., the investments and the structure directed to innovation in the past contribute to the constitution of the resource innovation in the present. The contribution derives not only from an additive process of investments but also 


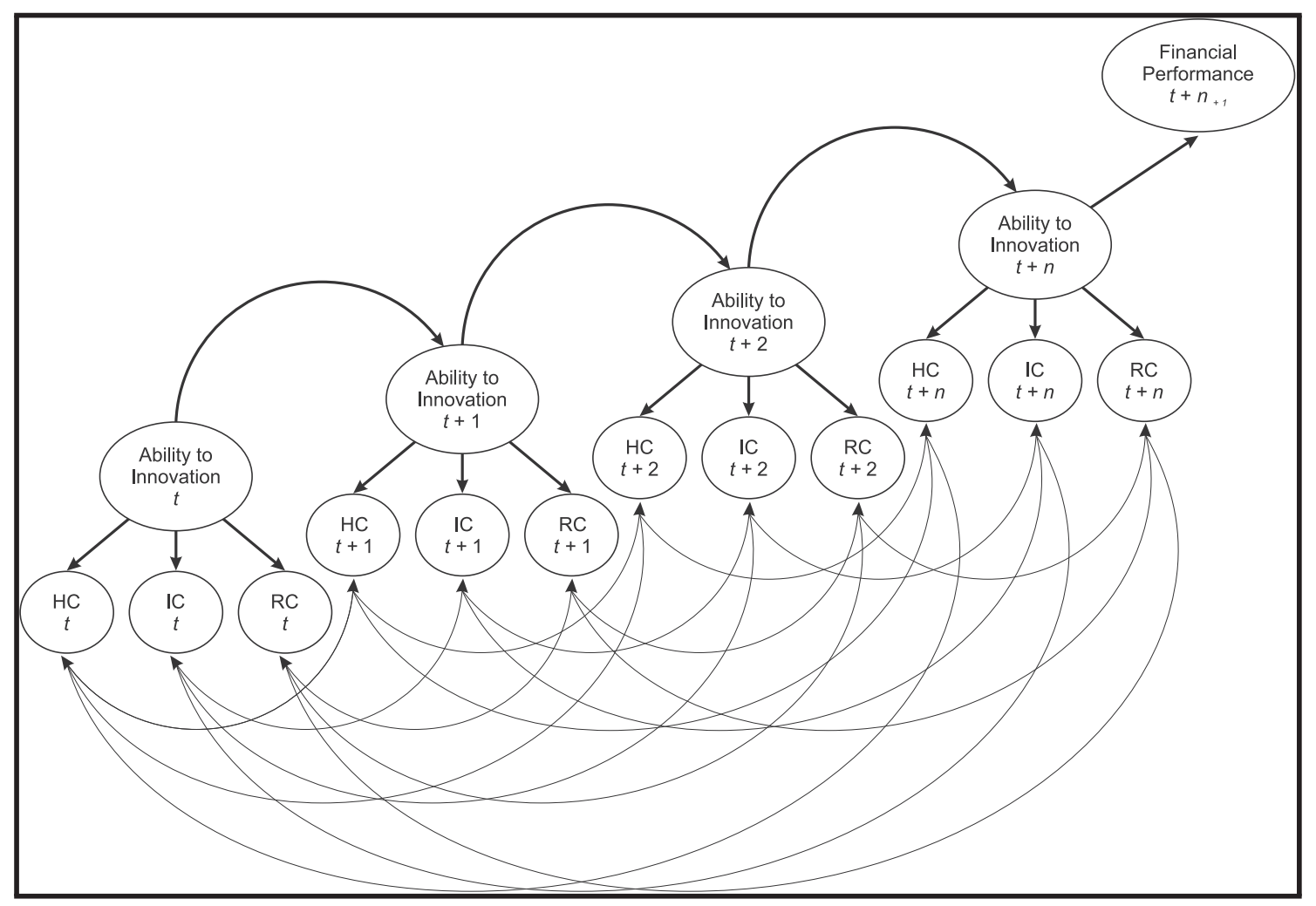

Fig. 1. Conceptual mdel for the cumulative trajectory of innovation.

through organizational learning capabilities (Bartoloni and Baussola, 2017). Thus, the capability to innovate is an organizational resource with cumulative nature of investments in the dimensions that constitute it, such as human capital, internal capital and relational capital.

The management of the ability to innovate as a complex firm resource that involves internal and external sources was also explored by Wang et al. (2017). The authors highlight the importance of managers in fostering a style of innovation-driven leadership as a way to exploit available resources that, in fact, contribute to value creation. In addition, Lichtenthaler (2016) shows that innovation, as a resource that reflects the absorptive capacity of companies, involves multiple internal and external variables, and has effects on financial performance that occur over time. which is in keeping with the approach used in this study.

Other internal factors that, according to the literature, are responsible for the ability to innovate or generate innovations include the following: training (Liao and Rice, 2010); project development; marketing for the introduction of a new product (Kim et al., 2016); organizational changes (Hu, 2014) and the acquisition of machinery and equipment (Hashi and Stojčić, 2013; Lööf and Heshmati, 2006; Urgal et al., 2011).

External factors for innovation are more recent in empirical studies that discuss the impact of innovation on financial performance $\mathrm{CHu}$, 2014; Kostopoulos et al., 2011). This situation stems from, among other factors, the increased complexity and specialization of knowledge (Cruz-González et al., 2015; Hung and Chou, 2013; Ritala et al., 2015; Ye et al., 2016). Investments in the development of external R \& D and the acquisition of external knowledge have become relevant for firms' ability to innovate (Bäck and Kohtamäki, 2015; Cruz-González et al., 2015; Wang and Wang, 2012; Ye et al., 2016).

Regardless of the configurations and levels of investment in innovation, all strategies that are associated with this resource should be directed to the creation of value that, in turn, can occur immediately or be reflected only in the long run (Bernardo, 2014; Lancker et al., 2016).

The metrics for discriminating financial and economic results are more consolidated than the innovation indicators. However, associating investments in innovation with the financial performance of companies is still a controversial topic with regard to the methods and period of analysis, particularly in emerging countries (Atalay et al., 2013; Santos et al., 2014). Nevertheless, the availability of information and the reliability of the verification process of primary data at the firm level are important elements for the validity of the empirical model (Klingenberg et al., 2013).

The following are the main metrics that are used to analyze the financial performance of innovation resources: Return on Assets (ROA) and Return on Investment (ROI) (Klingenberg et al., 2013; Liao and Rice, 2010; Wang and Wang, 2012); Return on Equity (ROE): (Liao and Rice, 2010); Return on Sales (ROS): (Kostopoulos et al., 2011); and the EBTIDA margin (Klingenberg et al., 2013).

Considering the theoretical discussion, Fig. 1 illustrates the conceptual model that is proposed for analyzing the influence of the cumulative trajectory of the ability to innovate on the financial performance of companies. The model presents innovation as a resource, i.e., an (intangible) asset of the organization that is oriented towards the generation of economic results from the combination of different factors, segregated here into human capital, internal capital, and relational capital (Santos et al., 2014; Sundbo and Gallouj, 2000; Urgal et al., 2011).

\section{Materials and methods}

\subsection{Materials}

The database was built with two of Brazil's major sets of business information, the Annual Industrial Survey (PIA) and the Technological Innovation Survey (PINTEC), between 2000 and 2012. Both surveys are managed by the Brazilian Institute of Geography and Statistics (IBGE). The radical of the codes of the National Register of Legal Entities (CNPJ) was used at the enterprise level to combine the two databases.

The PIA is an annual survey that comprises more than 56,000 
Table 1

Sectorial stratification of the study sample.

\begin{tabular}{|c|c|c|c|c|c|c|c|}
\hline Sectors & $2000 / 2011$ & $2000 / 2001$ & $2003 / 2004$ & $2005 / 2006$ & $2008 / 2009$ & $2011 / 2012$ & Mean \\
\hline Manufacture of food products and beverages & 250 & 1020 & 1012 & 1339 & 1420 & 1302 & 1219 \\
\hline Manufacture of machinery and equipment & 126 & 547 & 506 & 656 & 941 & 945 & 719 \\
\hline Manufacture of chemicals and pharmaceutical chemicals & 109 & 535 & 468 & 600 & 730 & 685 & 604 \\
\hline Manufacture of textiles & 105 & 404 & 353 & 445 & 506 & 433 & 428 \\
\hline Manufacture of furniture and wood products & 80 & 551 & 489 & 640 & 684 & 643 & 601 \\
\hline Manufacture of leather goods and footwear & 67 & 377 & 355 & 498 & 465 & 397 & 418 \\
\hline Manufacture and assembly of motor vehicles, trailers, and bodies & 65 & 278 & 262 & 364 & 515 & 433 & 370 \\
\hline Manufacture of office machines, computers, and communication equipment & 63 & 160 & 144 & 194 & 356 & 283 & 227 \\
\hline Manufacture of metal products, excluding machinery and equipment & 62 & 451 & 439 & 578 & 757 & 719 & 589 \\
\hline Manufacture of clothing items and accessories & 55 & 453 & 405 & 642 & 570 & 523 & 519 \\
\hline Manufacture of rubber items and plastic materials & 55 & 479 & 426 & 576 & 751 & 678 & 582 \\
\hline Manufacture of pulp, paper, and paper products & 52 & 236 & 207 & 252 & 358 & 285 & 268 \\
\hline Manufacture of machinery, appliances, and electrical equipment & 49 & 224 & 214 & 264 & 371 & 346 & 284 \\
\hline Manufacture of non-metallic mineral products & 46 & 385 & 325 & 482 & 530 & 511 & 447 \\
\hline Metallurgy & 42 & 195 & 193 & 250 & 329 & 270 & 247 \\
\hline Manufacture of wood products & 34 & 316 & 270 & 369 & 332 & 257 & 309 \\
\hline $\begin{array}{l}\text { Manufacture of coke, petroleum refining, development of nuclear fuels, } \\
\text { and alcohol production }\end{array}$ & 34 & 100 & 114 & 107 & 152 & 116 & 118 \\
\hline Manufacture of other transport equipment & 21 & 55 & 84 & 105 & 96 & 96 & 87 \\
\hline Extraction of non-metallic minerals & 13 & 122 & 106 & 141 & 153 & 184 & 141 \\
\hline Editing, printing, and reproduction of recorded media & 11 & 254 & 203 & 279 & 128 & 147 & 202 \\
\hline Other sectors & 1 & 9 & 5 & 7 & 13 & 16 & 10 \\
\hline Coal extraction & 0 & 10 & 0 & 0 & 6 & 10 & 5 \\
\hline Oil extraction and related services & 0 & 0 & 15 & 21 & 5 & 12 & 11 \\
\hline Extraction of metallic minerals & 0 & 27 & 20 & 22 & 26 & 14 & 22 \\
\hline Manufacture of tobacco products & 0 & 19 & 23 & 24 & 25 & 22 & 23 \\
\hline Total & 1340 & 7207 & 6638 & 8855 & 10,219 & 9327 & 8449 \\
\hline
\end{tabular}

industrial companies in Brazil with more than 30 employees or revenues exceeding US\$ 3.2 million, and it has been conducted since 1996. First published in 2000, the PINTEC is a triennial survey; its questionnaire follows the Oslo Manual, and the structure is similar to that of the Community Innovation Survey (CIS). The last published edition of the PINTEC (2011) covered 116,632 industries with more than 10 employees, and therefore, the sample is wider than that of the PIA.

Considering the availability of the database, five cross-sectional samples were constructed, i.e., 2000/2001, 2003/2004, 2005/2006, $2008 / 2009$, and $2011 / 2012$, in addition to a sixth sample with data from all years for only the companies that presented results in all editions of the PINTEC, thus constituting a balanced panel.

After the combination and validation of the samples, the empirical study involved an analysis in a restricted environment of IBGE in the city of Rio de Janeiro called the 'secret room'. The results of the analysis are available only with the approval of IBGE technicians who assess the confidentiality and security of the information of the respondent companies.

Table 1 discriminates the 25 industrial sectors of the cross-sectional samples and the longitudinal sample of companies between the 2000 and 2011.

The variations between years are due to the difference in the scope of the studies, the opening and closing of companies, and movements of corporate demerger, and the merger and acquisition of companies. The reduction in the companies in the longitudinal sample is a reflex of the intersection between the cross-sectional periods.

The first seven sectors account for over $50 \%$ of the companies in the sample, but the distribution is not concentrated, which depicts Brazil's heterogeneous industrial profile. It was not possible to extract descriptive results per sector due to IBGE's requirement to restrict the results to sectors with at least 100 companies in all samples.

Despite the differences among sectors, there is empirical evidence that there is a common technological trajectory for Brazilian industry based on the similarities in the external conditions for all companies and the dominant market perspective focused on the domestic market, which is still very protected by public policies (Castellacci and Natera, 2016).
The operationalization of the variables of interest occurred as shown in Table 2, and all variables were standardized by subtracting the values observed by the sample mean and dividing by the sample standard deviation.

\subsection{Method}

Factor analysis was used as a method of verifying the interdependence between the variables and their congregation in common factors, as represented by the latent variables $\mathrm{HC}$, IC, and RC of the theoretical model in Fig. 1.

The dimensions that are derived from factor analysis are vectors that minimize the distances between the individual values and express similarities (Dray, 2008). The matrix model follows Eq. (1) (Audigier et al., 2014).

$\mathbf{X}-\mu=\Lambda \mathbf{F}+\epsilon$

where $(\mathbf{X}-\boldsymbol{\mu})$ is the difference between a real-valued vector $(\mathbf{X}=$ $\left.\left[X_{1}, X_{2}, \cdots, X_{n}\right]^{T}\right)$ and a mean vector $\left(\boldsymbol{\mu}=\left[\mu_{1}, \mu_{2}, \cdots, \mu_{n}\right]^{T}\right)$, and the variance-covariance matrix is positive. $X_{i}$ represents measured variables depicted in Table 2, corresponding to dimensions of human capital, internal capital and relational capital. The observable variables can be expressed as a linear function of $p$ latent variables or factors, where $p<n$. The latent variables $F_{i}$ constitute a vector $\mathbf{F}=\left[F_{1}, F_{2}, \cdots, F_{p}\right]^{T}$, uncorrelated with the error term $\epsilon$, related to the corresponding observable variable $X_{i}$. In the context of this study, we aim to analyze whether the structure of investments in innovation, taking into account the measured variables, reflects the latent dimensions studied in the literature.

Following the evaluation of the factor analysis, based on structural equation modelling, a combination of three techniques was used: i) a latent trajectory, (ii) an autoregressive model (Delsing and Oud, 2008; Geiser et al., 2013), and (iii) a multilevel structure (Yuan and Bentler, 2007).

This combination of techniques allows modelling, through time, innovation as a construct that cannot be directly observed by a single measured variable. Traditional multivariate regression analysis, 
Table 2

Variables used in this research.

\begin{tabular}{|c|c|c|c|}
\hline $\begin{array}{l}\text { Reflective latent } \\
\text { variables }\end{array}$ & $\begin{array}{l}\text { Description of the } \\
\text { observable variables }\end{array}$ & Calculation & Source \\
\hline \multirow[t]{4}{*}{$\begin{array}{l}\text { Human Capital } \\
\text { (HC) }\end{array}$} & Doctorate (PhD) (v8) & $\frac{\text { Doctors }}{\text { Total employees }}$ & PINTEC \\
\hline & Master's (Ma) (v9) & $\frac{\text { Masters }}{\text { Total employees }}$ & PINTEC \\
\hline & Bachelor's (Bach) (v10) & $\frac{\text { Bachelors }}{\text { Total employees }}$ & PINTEC \\
\hline & Technicians (Tec) (v11) & $\frac{\text { Technicians }}{\text { Total employees }}$ & PINTEC \\
\hline \multirow[t]{5}{*}{$\begin{array}{l}\text { Internal Capital } \\
\text { (IC) (v1) }\end{array}$} & Internal R \& D (IRD) & $\frac{\text { Internal R\&D }}{\text { Revenue }}$ & PINTEC \\
\hline & $\begin{array}{l}\text { Acquisition of } \\
\text { Machinery and } \\
\text { Equipment (AME) (v2) }\end{array}$ & $\frac{\text { Investment in Mac.and Equip }}{\text { Revenue }}$ & PINTEC \\
\hline & Training (TR) (v3) & $\frac{\text { Training }}{\text { Revenue }}$ & PINTEC \\
\hline & $\begin{array}{l}\text { Introduction of } \\
\text { Technological } \\
\text { Innovation (ITI) (v4) }\end{array}$ & $\frac{\text { Invest.Introd.Innovation }}{\text { Revenue }}$ & PINTEC \\
\hline & $\begin{array}{l}\text { Industrial Projects (IP) } \\
\text { (v5) }\end{array}$ & $\frac{\text { Invest.in Industrial Projects }}{\text { Revenue }}$ & PINTEC \\
\hline \multirow[t]{2}{*}{$\begin{array}{l}\text { External Capital } \\
\quad \text { (RC) }\end{array}$} & $\begin{array}{l}\text { External R \& D (ERD) } \\
\text { (v6) }\end{array}$ & $\frac{\text { Invest.in External R \& D }}{\text { Revenue }}$ & PINTEC \\
\hline & $\begin{array}{l}\text { Acquisition of Other } \\
\text { Knowledge (AOK) (v7) }\end{array}$ & $\frac{\text { Invest.in Other Knowled. }}{\text { Revenue }}$ & PINTEC \\
\hline $\begin{array}{c}\text { Formative latent } \\
\text { variable }\end{array}$ & $\begin{array}{l}\text { Description of } \\
\text { observable variables }\end{array}$ & Calculation & Source \\
\hline \multirow{2}{*}{$\begin{array}{l}\text { Financial } \\
\text { performance } \\
\text { (FP) }\end{array}$} & ROA (v12) & $\frac{\text { Operating Net Profit. }}{\text { Total Investment }}$ & PIA \\
\hline & $\begin{array}{l}\text { Cash Generation (CG) } \\
\text { (v13) }\end{array}$ & $\frac{\text { EBTIDA }}{\text { Revenue }}$ & PIA \\
\hline
\end{tabular}

regardless of using cross section, longitudinal or panel data, would require a single observed variable to represent a proxy for the concept of innovation. This limitation has also been discussed in other studies, such as Cammarano et al. (2017), Luo et al. (2017)and Stefan and Bengtsson (2017). Due to the complexity of the innovation concept, SEM would allow considering innovation as a latent construct associated with various variables.

Although regression with panel data could be used for analyzing cross-section and temporal observations, unfortunately in our case, the number of firms is high, but the number of years is small. In addition, the Brazilian Institute of Geography and Statistics does not conduct and publish PINTEC and PIA surveys following a constant frequency, which is critical for the use of traditional panel data techniques. We therefore chose longitudinal SEM, which makes possible a representation of innovation as a non-observable latent variable and allows a framework to analyze relationships between constructs over time.

A latent trajectory model identifies the dynamics of a construct in different moments in time due to changes in the variables that give rise to it, according to Eq. (2) (Geiser et al., 2013).

$y_{i, t}=\xi_{i, t}+\zeta_{i, t}+\epsilon_{i, t}$

where $y$ is the ability to innovate (estimated construct), $i$ refers to observations, and $t=0,1,2, \cdots, s$ is the point in time when the values for each variable are presented. It is important to show that $\xi$ characterizes the observation unit that generates the indicator for the observed variable. $\zeta$ is a specific residual indicator of the latent variable that characterizes the interaction between the observation units and the time when they were included. In the study we conducted, we consider $t$ as a consecutive integer number related to the order of the PINTEC release dates, since IBGE does not provide yearly data. This strategy aims to show evidence of the effect on the construct, ability to innovate, of investments realized in different moments of the time $(0,1,2, \cdots, s)$, since the time of observations $i$ must be less than the time of $y$. Finally, $\epsilon$ is the residual error term.

The association of the latent trajectory with the autoregressive model is due to the theoretical assumption that the latent variables are hierarchically arranged in time (Cantwell and Fai, 1999; Castellacci, 2008). The possibility of associating the autoregressive model with the trajectory of the latent variable is predicted by Bollen and Curran (2004), according to Eq. (3).

$y_{i, t}=\alpha_{i}+\Lambda_{t 2} \beta_{i}+\rho_{t, t-1} y_{i, t-1}+\epsilon_{i, t}$

The extension for a bivariate (two latent variables) may be defined by Eqs. (4) and (5)(Bollen and Curran, 2004; Delsing and Oud, 2008).

$y_{i, t}=\alpha_{y i}+\Lambda_{y t 2} \beta_{y i}+\rho_{y_{t} y_{t-1}} y_{i, t-1}+\rho_{y_{t} x_{t-1}} x_{i, t-1}+\epsilon_{y i, t}$

$x_{i, t}=\alpha_{x i}+\Lambda_{x t 2} \beta_{x i}+\rho_{x_{t} x_{t-1}} x_{i, t-1}+\rho_{x_{t} y_{t-1}} y_{i, t-1}+\epsilon_{x i, t}$

As assumptions, the error terms should have a zero mean and cannot be correlated with the other variables (Bollen and Curran, 2004). Because of the possibility of multiple variables, Bollen and Curran (2004) postulate a simple matrix expression with two equations that describe the autoregressive model with a latent trajectory (Eqs. (6) and (7)).

$\eta_{i}=\mu+\mathrm{B}_{\eta_{i}}+\zeta_{i}$

$\mathrm{o}_{i}=\mathrm{P}_{\eta_{i}}$

The expression presupposes a structural relationship between the variables; thus, $\eta_{i}$ is the vector that gathers the observable variables, the intercepts, and the covariances; $\mu$ is the vector of the means or intercepts; $\mathrm{B}$ is the matrix coefficient resulting from the coefficients of the relationships established in the vector $\eta_{i}$; and $\zeta_{i}$ is the residual vector.

Table 3

Descriptive results of the samples in the study (\%).

\begin{tabular}{|c|c|c|c|c|c|c|c|c|c|c|c|c|}
\hline \multirow[t]{2}{*}{ Variables } & \multicolumn{2}{|c|}{$2000 / 2001$} & \multicolumn{2}{|c|}{$2003 / 2004$} & \multicolumn{2}{|c|}{$2005 / 2006$} & \multicolumn{2}{|c|}{$2008 / 2009$} & \multicolumn{2}{|c|}{$2011 / 2012$} & \multicolumn{2}{|c|}{ Longitudinal } \\
\hline & $x$ & $s$ & $\overline{\boldsymbol{x}}$ & $s$ & $\overline{\boldsymbol{x}}$ & $s$ & $\overline{\boldsymbol{x}}$ & $s$ & $\overline{\boldsymbol{x}}$ & $s$ & $\overline{\boldsymbol{x}}$ & $x$ \\
\hline IRD & 0.74 & 14.31 & 0.57 & 9.28 & 0.53 & 11.33 & 0.00 & 0.00 & 0.60 & 7.43 & 0.58 & 3.55 \\
\hline ERD & 0.07 & 0.59 & 0.05 & 0.55 & 0.03 & 0.43 & -0.00 & 0.00 & 0.06 & 0.74 & 0.06 & 0.50 \\
\hline AOK & 0.14 & 1.62 & 0.10 & 2.27 & 0.44 & 23.84 & 0.00 & 0.00 & 0.20 & 3.14 & 0.13 & 1.26 \\
\hline AME & 4.35 & 62.23 & 2.17 & 13.2 & 3.09 & 63.42 & 0.00 & 0.02 & 3.80 & 102.5 & 1.43 & 8.66 \\
\hline TR & 0.15 & 1.68 & 0.08 & 1.06 & 0.15 & 4.85 & 0.00 & 0.00 & 0.07 & 0.94 & 0.05 & 0.31 \\
\hline ITI & 0.27 & 4.29 & 0.20 & 4.46 & 0.24 & 5.32 & 0.00 & 0.00 & 0.17 & 3.53 & 0.16 & 0.76 \\
\hline IP & 0.56 & 5.88 & 0.55 & 5.03 & 0.36 & 2.37 & 0.00 & 0.01 & 0.31 & 5.11 & 0.29 & 1.83 \\
\hline $\mathrm{PhD}$ & 0.03 & 0.42 & 0.02 & 0.25 & 0.03 & 0.53 & 0.02 & 0.21 & 0.04 & 0.62 & 0.03 & 0.31 \\
\hline $\mathrm{Ma}$ & 0.06 & 0.50 & 0.07 & 0.81 & 0.06 & 0.60 & 0.07 & 1.06 & 0.07 & 1.25 & 0.08 & 0.45 \\
\hline Bach & 0.60 & 2.19 & 0.57 & 3.00 & 0.52 & 2.71 & 0.41 & 2.78 & 0.70 & 4.66 & 0.72 & 2.28 \\
\hline Tec. & 0.60 & 2.13 & 0.48 & 2.68 & 0.40 & 1.98 & 0.26 & 2.09 & 0.35 & 2.91 & 0.49 & 1.90 \\
\hline CG & 2.65 & 32.03 & 55.61 & 85.53 & 2.66 & 65.37 & 1.29 & 166.37 & 5.89 & 43.86 & 17.45 & 32.40 \\
\hline ROA & -2.86 & 674.14 & 584.29 & 29.756 & -23.15 & 2.787 . & 3.46 & 22.610 & 1.16 & 9.179 & 38.84 & 480.06 \\
\hline
\end{tabular}

Note: $\bar{x}$ is the average of the variables; $s$ is the standard deviation of the variables. 
Eq. (7) allows the observed variables $\left(\mathrm{O}_{i}\right)$ to be separated from the latent variables (Bollen and Curran, 2004).

Finally, this autoregressive structure of the latent variables is postulated in a multilevel structure of latent variables, according to Eqs. (8), (9), and (10) (Little, 2013).

$y_{i t c}=\mathrm{T}_{t c}+\Lambda_{t c} \eta_{o c}+\Theta_{i t c}$

$E\left(y_{i t c}\right)=\mu_{y_{t c}}=\mathrm{T}_{t c}+\Lambda_{t c} \mathrm{~A}_{t c}$

$\Sigma_{t c}=\Lambda_{t c} \Psi_{t c} \Lambda_{t c} \Theta_{i t c}$

where $i$ refers to the values of each individual company; $t$ is the time in which each of the individual values is taken; $c$ refers to the structure at the level in which the variables are grouped; $y$ are the coefficients of the variables; $\mu_{y}$ is the average of the vectors; $\mathrm{T}$ is the vector of the variables' mean; A is the vector of the latent variables' mean; $\Sigma$ is the implicit variance-covariance matrix of the model; $\eta$ is the vector that gathers the estimators of the latent variables; $\Lambda$ is the matrix of the factor loadings of the estimators of the relations between constructs; $\Theta$ is the matrix of residual variances; $\Psi$ is the matrix of covariances and variances between the constructs; and $\Lambda^{\prime}$ is the transposed matrix $\Lambda$ (Little, 2013).

Thus, all relationships anticipated in the theoretical model, including the observed variables, are set for this multilevel model with an autoregressive latent trajectory to be calculated by structural equation modelling. The two main tests for evaluating the adjustment of the model are RMSEA and CFI (Little, 2013; Yuan and Bentler, 2007).

The use of SEM dealing with innovation as a latent resource, with a relevant time path in a multilevel structure, aims to mimic the way the ability to innovate develops within the firm. In this context, the method allows the estimation of the impact of investments in innovation as a multidimensional construct, on financial performance. The autoregressive model explores the effects of investments in innovation throughout the years, taking into account, the cumulative characteristic of these innovation efforts as suggested by Cantwell and Fai (1999).

\section{Results and discussions}

Table 3 shows the descriptive results of the variables used for the cross-sectional and longitudinal samples that compose this study.

It is noted that for all variables, there is a high dispersion of results, which shows relevant differences in the investment strategies in innovation of Brazilian companies and in the composition of the structure of human capital. A high dispersion in the metrics that are associated with financial performance is also identified. It is verified in the 2008/ 2009 sample that there is a reduction in the average investment in innovation. This fact has also been evidenced by (Paunov, 2012).

The manner in which investments in innovation are organized in Brazilian films' ability to innovate can be identified by the factor analysis presented in Table 4.

For the first and last samples, the model adjusted better with six factors and the others with five; the total explained variance exceeded $70 \%$. For parsimony, Table 4 presents only the factors that gathered more than one variable with a coefficient above 0.4 . The tests that were anticipated for the KMO and Bartlett's sphericity factor analysis allow the reliability of the grouping of factors to be accepted.

The grouping of the factors does not reflect a standard structure of innovation over time, as initially expected by the theoretical model and provided in the study by Santos et al. (2014). However, the relevant variables interspersed over time and indicate that during the period, there can be a dynamic in their management and, indeed, different forms of configuration.

It is emphasized that the variables that were anticipated for financial performance showed a higher correlation between them than the factors that gather the innovation variables. These results suggest that the construct of financial performance is formed by the constructs

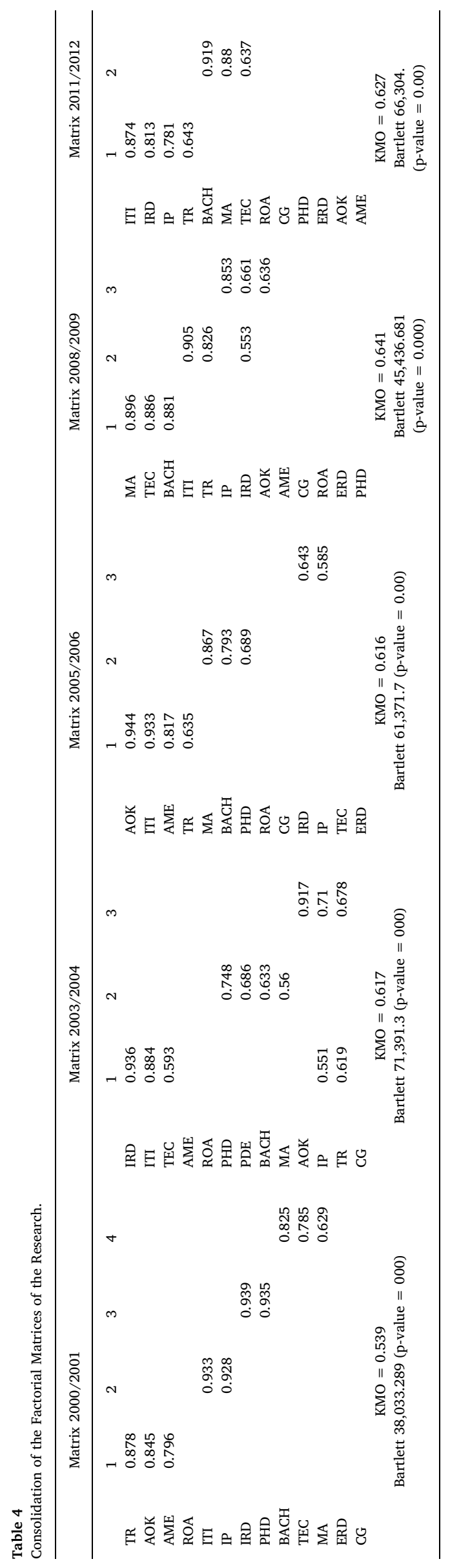


Table 5

Aggregated results of the cross-sectional samples of the PINTEC.

\begin{tabular}{|c|c|c|c|c|c|c|}
\hline \multicolumn{2}{|l|}{ Relations between } & \multirow{2}{*}{$\frac{2000 / 2001}{\text { Estimate }}$} & \multirow{2}{*}{$\begin{array}{l}2003 / 2004 \\
\text { Estimate }\end{array}$} & \multirow{2}{*}{$\begin{array}{l}2005 / 2006 \\
\text { Estimate }\end{array}$} & \multirow{2}{*}{$\begin{array}{l}2008 / 2009 \\
\text { Estimate }\end{array}$} & \multirow{2}{*}{$\begin{array}{l}2011 / 2012 \\
\text { Estimate }\end{array}$} \\
\hline & & & & & & \\
\hline \multicolumn{7}{|l|}{ Constructs } \\
\hline ABIN & $\mathrm{HC}$ & $0.087^{* * *}$ & $0.181^{* * *}$ & $0.62^{* * *}$ & $0.353^{* * *}$ & $0.067^{* * *}$ \\
\hline ABIN & IC & $0.725^{* * *}$ & $0.671^{* * * k}$ & $0.733^{* * *}$ & $0.684^{* * *}$ & $0.962^{* * *}$ \\
\hline ABIN & $\mathrm{RC}$ & $0.362^{* * *}$ & $0.374 * * *$ & $0.016^{* * *}$ & $0.311^{* * *}$ & $0.149 * * *$ \\
\hline FP & ABIN & $0.44^{* * *}$ & 0.002 & $0.085^{* * *}$ & $-0.166^{* * *}$ & 0.008 \\
\hline PHD & $\mathrm{HC}$ & $0.465^{* * *}$ & $0.545^{* * *}$ & $0.294 * * *$ & $0.408^{* * *}$ & $0.155^{* * *}$ \\
\hline MA & $\mathrm{HC}$ & $0.073^{* * *}$ & $0.317^{* * *}$ & $0.972^{* * *}$ & $0.878^{* * *}$ & $0.612^{* * *}$ \\
\hline BACH & $\mathrm{HC}$ & $0.361^{* * *}$ & $0.647^{* * *}$ & $0.38^{* * *}$ & $0.769^{* * *}$ & $1.353^{* * *}$ \\
\hline TEC & $\mathrm{HC}$ & $0.564^{* * *}$ & $0.407^{* * *}$ & $0.026^{* * *}$ & $0.498^{* * *}$ & $0.005^{* * *}$ \\
\hline IRD & IC & $0.643^{* * *}$ & $0.936^{* * *}$ & $0.604 * * *$ & $0.888^{* * *}$ & $0.844^{* * *}$ \\
\hline AME & IC & $0.332^{* * *}$ & $0.383^{* * *}$ & $0.016^{* * *}$ & $0.122^{* * *}$ & 0.001 \\
\hline TR & IC & $0.155^{\text {*k* }}$ & $0.753^{* * *}$ & $0.533^{* * *}$ & $0.739 * * *$ & $0.551^{* * *}$ \\
\hline ITI & IC & $0.949^{* * *}$ & $0.953^{* * *}$ & $0.956^{* * *}$ & $0.436^{* * *}$ & $0.891^{\text {*** }}$ \\
\hline IP & IC & $0.823^{* * *}$ & $0.68^{* * *}$ & $0.093^{* * *}$ & $0.833^{* * *}$ & $0.745^{* * *}$ \\
\hline ERD & $\mathrm{RC}$ & $0.465^{* * *}$ & $0.545^{* * *}$ & $0.294 * * *$ & $0.408^{* * *}$ & $0.155^{* * *}$ \\
\hline AOK & RC & $0.073^{* * *}$ & $0.317^{* * *}$ & $0.972^{* * *}$ & $0.878^{* * *}$ & $0.612^{* * *}$ \\
\hline ROA & FP & $0.906^{* * *}$ & $0.143^{* * *}$ & $0.358^{* * *}$ & $0.064^{* * *}$ & $1.352^{* * *}$ \\
\hline EBTIDAM & FP & $0.155^{* * *}$ & $0.387^{* * *}$ & $0.96^{* * *}$ & $0.563^{* * *}$ & $0.044 * * *$ \\
\hline \multicolumn{7}{|c|}{ Result of the covariances of the latent variables } \\
\hline$<->$ & IC & $0.117^{\text {*** }}$ & $0.461^{* * *}$ & $0.026^{* *}$ & $0.163^{* * *}$ & $0.194^{* * *}$ \\
\hline$<->$ & IC & $-0.144^{* * *}$ & $0.123^{* * *}$ & $0.996 * * *$ & $0.436^{* * *}$ & $0.073^{* * *}$ \\
\hline$<->$ & $\mathrm{HC}$ & $0.161^{* * *}$ & $0.75^{* * *}$ & 0.011 & $0.065^{* * *}$ & $0.048^{* * *}$ \\
\hline \multicolumn{7}{|l|}{ Adjustment tests } \\
\hline & RMSEA & 0.2 & 0.19 & 0.137 & 0.138 & 0.11 \\
\hline & CFI & 0.09 & 0.561 & 0.563 & 0.622 & 0.751 \\
\hline
\end{tabular}

*** Significance: $1 \%$.

of innovation and non-reflexive.

The cross-sectional analysis of the influence of innovation on financial performance was conducted with the aid of five structural equation models, whose consolidated results are shown in Table 5.

It is verified that except for AME in 2011, all observable variables were significant and positive in the formation of the latent variables of the model (HC, IC, and RC). These three latent variables were significant and had a positive influence on the construct of ability to innovate, demonstrating, for the first time for the Brazilian reality, this structure for this organizational resource, innovation. It is also emphasized that the covariances among the latent variables of HC, IC, and RC were significant and positive in almost every year. However, the adjustment tests do not allow the reliability of the model to be confirmed with the available data, despite the improved testing over time. In the last year of analysis, RMSEA was 0.11 , which is a value close to the maximum acceptable limit of 0.10 .

The construction of the trajectory model prioritized an evolutionary analysis of the structure dedicated to innovation, from 2000 to 2011, and the financial results were updated considering the year following the last aggregated information. Fig. 2 shows the complete studied model. In the construction of this model, there are a total of 159 coefficients, 125 covariances, and 85 variances, and 125 parameters are estimated for a total of 1340 companies, repeated at five periods, resulting in 2086 degrees of freedom.

Table 6 shows the estimated coefficients of the regressions.

The RMSEA of the independent model was 0.105, which allows the model to be accepted at the limit of approximately $90 \%$. However, the standardized values of the regression variables of the ability to innovate on financial performance were at the value of 1.0, and this value is considered to be a transgressor in structural equation modelling (Little, 2013).

It is noteworthy that for the entire period, the influence of resource innovation on financial performance is positive and significant, except for the $2008 / 2009$. It is observed that the influence of the ability to innovate (ABIN) in 2011 is greater than the rest.

All independent variables were significant for the construction of the first-level latent variables in the entire period (HC, RC, IC).
However, it is noted that there is significance for the construct of resource innovation only for 2000 and that IC is significant in explaining the ABIN in 2003 and 2005.

The autoregressive process of resource innovation presented positive estimators throughout the period but without significance. All covariances between the observable variables and the first-level latent variables were positive and significant.

Given this indication, the analysis of the model was conducted without the autoregressive process of the ABIN, considering only the multilevel process and the trajectory of the latent variable. Fig. 3 shows the structural equation modelling and the influence on financial performance for 2012 only.

The RMSEA presented the statistic of 0.111 slightly below the previous model, which keeps a fragile adjustment. However, considering the exploratory nature of this study and the complexity of the model, which involves a number of variables (138), estimators (59), and covariances (125), the reliability of $88 \%$ is judged as acceptable.

Table 7 shows the results of the estimators of the model with the trajectory of the ABIN.

All variables that compose the first-level latent variables were significant and had estimates with positive coefficients. Similar to the other model, the ABIN construct showed a significant and positive impact on financial performance. Moreover, in this model, the ABIN also impacted CG, which in turn also had a positive and significant influence on financial performance.

Among the first- and second-level latent variables, it is observed that with the exception of the IC and RC of 2008 and 2011, all were significant in the composition of the ABIN, and the positive and significant influence of the HC on the ABIN stands out throughout the period.

All covariances between provided in the model were positive and significant. Thus, the results suggest that initially, the cumulative process of the ABIN does not necessarily occur in a causal relationship but rather in an aggregation of competences in the constitution of this intangible asset.

The factor analysis and the significance of the variables in the crosssectional models for the formation of the latent variables validate a 


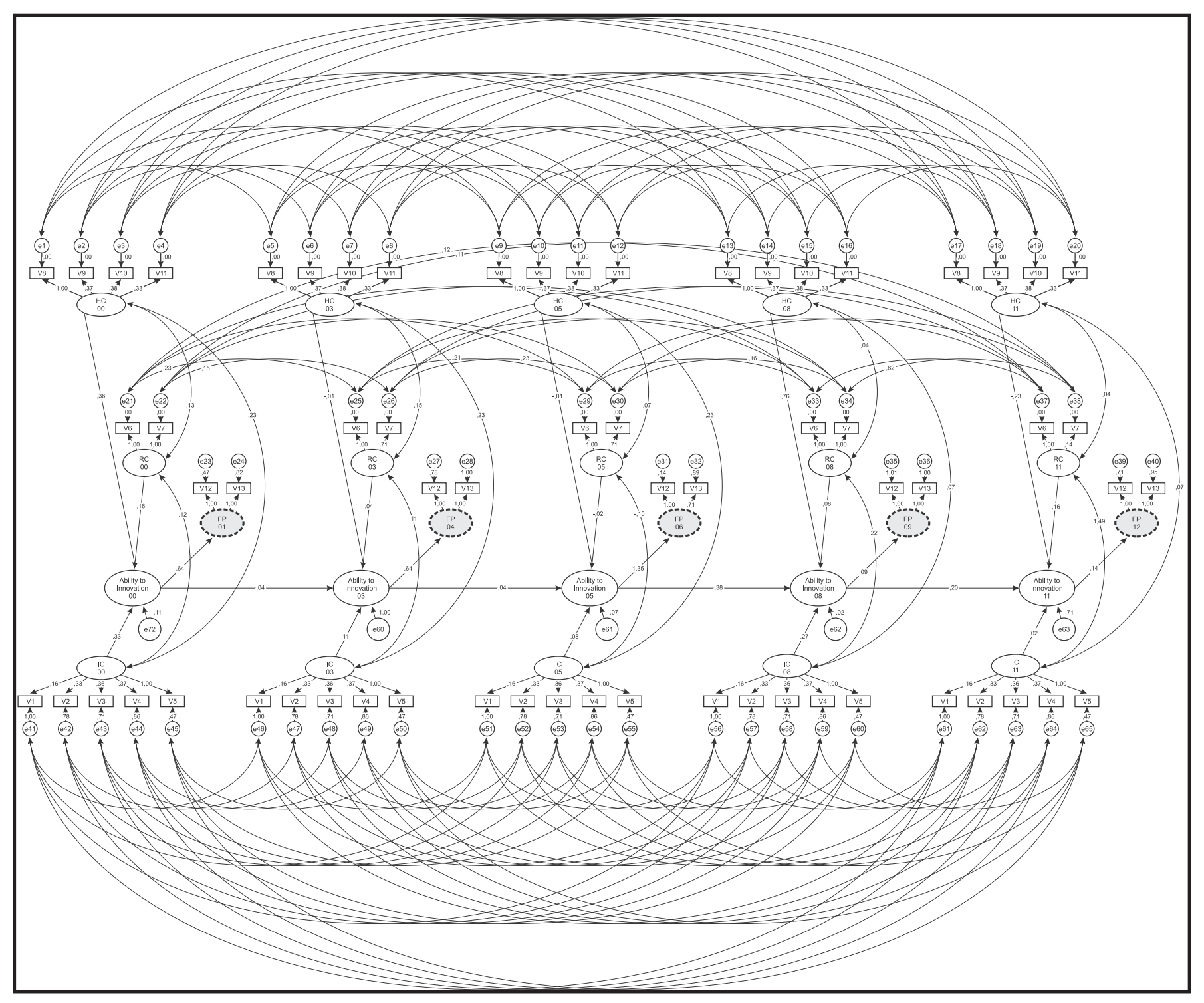

Fig. 2. Innovation management model with trajectory.

structure of the ABIN of companies based on HC, represented by the profile of the firms' professionals dedicated to $\mathrm{R} \& \mathrm{D}$, the investments in the ABIN made internally, and investments in the construction and acquisition of knowledge in networks. The literature occasionally explores these investments in a stratified manner; in other cases, the sources of information are taken through surveys. In this study, it was possible to show an integrated structure for firms' ABIN with the discrimination of all variables.

The literature points to the obstacles in analyzing business innovation, due to the difficulty in measuring associated variables and the complexity of its relationships with other variables. For Shafique (2012), innovation as an organizational resource can be considered a black box. In our study, we take into account constructs that are related to innovation and discussed in the literature.

Results of the study contribute to the understanding of the construct ABIN, strengthening the structural concept from the constructs related to internal, external and human resources (IC, RC, HC, respectively), and extending results from other studies, e.g., Santos et al. (2014). It is important to highlight that, in some studies, e.g., Crossan and Apaydin (2009), these resources are individually analyzed regardless of whether the approach focused on their impact on innovation or financial performance.
The correlations between these different resources depicted in Figs. 2 and 3 indicate that the complexity of investments in business innovation should take in account not only individual elements but a combination of them. The structure of IC as a resource that brings together investments in Internal R \& D (Howell, 2016), training (Liao and Rice, 2010), machine acquisition (Hashi and Stojčić, 2013), introduction of technological innovation and industrial projects, extends the discussion of the results achieved by specific research on these variables, e.g., Frank et al. (2016).

The results from the study also indicate the importance of the interaction of external and internal knowledge with innovation (de Moraes Silva et al., 2017; Wang et al., 2012). Such evidence was already discussed in the literature, but the relationship between external sources to innovation has been analyzed separately from that of internal resources to the innovation capability (Ye et al., 2016).

The significance of the multilevel structure of ABIN strengthens the conceptual proposal regarding the intangibility of the resource innovation, how dynamic it is and how it influences financial performance (Bernardo, 2014). Considering the difficulty in specifically structuring the innovation resource or the frequent arguments pointing out that innovation is constituted by multiple sources and depends on a cumulative process, our study helps better understand the complex 
Table 6

Results of the model with the trajectory and autoregression of the latent variable of innovation.

\begin{tabular}{|c|c|c|}
\hline Variables & Variables & Coefficients \\
\hline ABIN_00 & HC_00 & $0.312^{* * * *}$ \\
\hline ABIN_00 & IC_00 & $0.0283^{* k * x}$ \\
\hline ABIN_00 & RC_00 & $0.140^{\text {k玄 }}$ \\
\hline ABIN_03 & RC_03 & -0.036 \\
\hline ABIN_03 & HC_03 & -0.013 \\
\hline ABIN_03 & IC_03 & $0.105^{*}$ \\
\hline ABIN_03 & ABIN_01 & 0.048 \\
\hline ABIN_05 & IC_05 & $0.114^{k * *}$ \\
\hline ABIN_05 & RC_05 & -0.021 \\
\hline ABIN_05 & ABIN_03 & 0.063 \\
\hline ABIN_05 & HC_05 & -0.008 \\
\hline ABIN_08 & ABIN_05 & 0.272 \\
\hline ABIN_08 & RC_08 & 0.084 \\
\hline ABIN_08 & HC_08 & 0.078 \\
\hline ABIN_08 & IC_08 & 0.189 \\
\hline ABIN_11 & ABIN_08 & 0.251 \\
\hline ABIN_11 & IC_11 & -0.025 \\
\hline ABIN_11 & RC_11 & 0.068 \\
\hline ABIN_11 & HC_11 & -0.026 \\
\hline FP_04 & ABIN_03 & $1.000^{* * * *}$ \\
\hline FP_06 & ABIN_05 & $1.000^{* \ldots * x}$ \\
\hline FP_09 & ABIN_08 & 1.000 \\
\hline FP_12 & ABIN_11 & $1.000^{* * * * *}$ \\
\hline FP_01 & ABIN_00 & $1.000^{* * *}$ \\
\hline IP_03 & IC_03 & $0.825^{k \cdots * x}$ \\
\hline ITI_03 & IC_03 & $0.378^{* \ldots * k}$ \\
\hline TR_03 & IC_03 & $0.394^{* * * *}$ \\
\hline AME_03 & IC_03 & $0.348^{\text {kn*t}}$ \\
\hline IRD_03 & IC_03 & $0.161^{k * * k}$ \\
\hline IP_05 & IC_05 & $0.707^{* * * *}$ \\
\hline ITI_05 & IC_05 & $0.475^{* * * *}$ \\
\hline TR_05 & IC_05 & $0.371^{k * 2 * x}$ \\
\hline AME_05 & IC_05 & $0.363^{* \ldots * *}$ \\
\hline IRD_05 & IC_05 & $0.181^{* * * *}$ \\
\hline IP_08 & IC_08 & 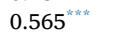 \\
\hline ITI_08 & IC_08 & $0.347^{* * * x}$ \\
\hline TR_08 & IC_08 & $0.264^{k \text { kn*t }}$ \\
\hline AME_08 & IC_08 & $0.258^{* * * *}$ \\
\hline IRD_08 & IC_08 & $0.125^{\text {k*k*k}}$ \\
\hline PHD_03 & $\mathrm{HC}_{-} 03$ & $0.825^{* \cdots * k}$ \\
\hline MA_03 & HC_03 & $0.378^{* * * *}$ \\
\hline BACH_03 & HC_03 & $0.394^{\text {k.***x}}$ \\
\hline TEC_03 & HC_03 & $0.348^{k * * x}$ \\
\hline PHD_05 & HC_05 & $0.825^{* \ldots * k}$ \\
\hline MA_05 & HC_05 & $0.378^{* \cdots *}$ \\
\hline BACH_05 & HC_05 & $0.394^{* * \cdots * x}$ \\
\hline TEC_05 & HC_05 & $0.348^{k * * *}$ \\
\hline PHD_08 & HC_08 & 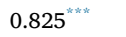 \\
\hline MA_08 & HC_08 & $0.378^{* \ldots * k}$ \\
\hline BACH_08 & HC_08 & $0.394^{k * * * x}$ \\
\hline TEC_08 & HC_08 & $0.348^{* * * *}$ \\
\hline IP_11 & IC_11 & $0.825^{* * *}$ \\
\hline ITI_11 & IC_11 & $0.378^{k \text { k⿻x/ }}$ \\
\hline TR_11 & IC_11 & $0.394^{* \ldots * *}$ \\
\hline AME_11 & IC_11 & $0.348^{* * * *}$ \\
\hline IRD_11 & IC_11 & $0.161^{* * * *}$ \\
\hline PHD_11 & HC_11 & $0.825^{\text {***k}}$ \\
\hline MA_11 & HC_11 & $0.378^{* * * *}$ \\
\hline BAC̄H_11 & HC_11 & $0.394^{* * * *}$ \\
\hline TEC_11 & HC_11 & $0.348^{\text {k*k* }}$ \\
\hline PHD_00 & HC_00 & $0.825^{* \ldots * *}$ \\
\hline MA_00 & HC_0O & $0.378^{* * * *}$ \\
\hline BAC̄H_00 & $\mathrm{HC}_{-} \mathrm{O} 0 \mathrm{O}$ & $0.394^{\text {t*k*t}}$ \\
\hline TEC_00 & HC_00 & $0.348^{k * k * k}$ \\
\hline IP_00 & IC_00 & $0.825^{* * * *}$ \\
\hline ITI_00 & IC_00 & $0.378^{* * * *}$ \\
\hline TR_00 & IC_00 & $0.394^{\text {th*tx}}$ \\
\hline AME_00 & IC_00 & $0.348^{k * * x}$ \\
\hline IRD_00 & IC_00 & $0.161^{* * * *}$ \\
\hline ERD_00 & RC_00 & $0.825^{* \ldots * k}$ \\
\hline AOK_00 & RC_00 & $0.378^{* * * * x}$ \\
\hline ERD_03 & RC_03 & $0.690^{* * * *}$ \\
\hline AOK_03 & RC_03 & $0.293^{k \ldots k t}$ \\
\hline
\end{tabular}

Table 6 (continued)

\begin{tabular}{|c|c|c|}
\hline Variables & Variables & Coefficients \\
\hline ERD_08 & RC_08 & $0.825^{\text {***k}}$ \\
\hline AOK_08 & RC_08 & $0.378^{* * * *}$ \\
\hline ERD_05 & RC_05 & $0.690^{* * * *}$ \\
\hline AOK_05 & RC_05 & $0.293^{* * *}$ \\
\hline ERD_11 & RC_11 & $0.364^{* * *}$ \\
\hline AOK_11 & RC_11 & $0.120^{* * * 1}$ \\
\hline ROA_03 & FP_04 & $0.586^{\text {***}}$ \\
\hline CG_03 & FP_04 & $0.231^{\text {*⿻心㇒ }}$ \\
\hline ROA_05 & FP_06 & $0.930^{* * * k}$ \\
\hline CG_05 & FP_06 & $0.337^{* * * k}$ \\
\hline ROA_08 & FP_09 & $0.086^{\text {***k}}$ \\
\hline CG_08 & FP_09 & $0.028^{* * * x}$ \\
\hline ROA_11 & FP_12 & $1.307^{\text {t*k*k}}$ \\
\hline CG_11 & FP_120 & $0.213^{\text {****}}$ \\
\hline ROA_01 & FP_01 & $0.733^{* \ldots * k}$ \\
\hline CG_01 & FP_01 & $0.289^{\text {***k}}$ \\
\hline
\end{tabular}

* Significance: $10 \%$

** Significance: $5 \%$.

$* * *$ Significance: $1 \%$.

relationships, taking advantage of an empirical study using a large database, which is updated from time to time.

In the longitudinal sample, all observable variables that underpin the model showed significant and positive covariances during the analyzed period, except for the variable Bach. This situation confirms the importance of continued investment in the sources of the ABIN over the course of time.

Still in the analysis of covariance, it is emphasized that the correlations between first-level constructs were significant and positive, which confirms the importance of integration between the various sources of the ABIN. Therefore, the construct of innovation presupposes that its constituent variables are understood in an integrated manner.

The ABIN structured in an autoregressive form did not show significant coefficients regarding its confirmatory factor structure, except for 2000 and the IC in two other periods. Despite the heterogeneity of the sample, it is verified that the innovation process does not require a static structure of investments in the sources of resource innovation but rather a dynamic view. It is noteworthy that $\mathrm{HC}$ was the only significant and positive finding in the formation of the ABIN in the analyzed period.

IC and RC showed variations in the confirmatory structure of the ABIN, and IC had a negative influence on the structure in 2000/2001 and 2011/2012, whereas RC was positive across the sample, except for 2008. These results suggest that the growth in resources for innovation and the policies established in Brazil in this period allowed the growth in companies' ABIN by 2011, whose negative result can express the limitation in making effective the expenditure on innovation along with business performance, or the negative marginal growth in the learning curve, after the initial trajectory of the ABIN is established.

The lower representativeness of the expenditure with RC in the early years of the project confirms the dependence of the innovation process provided on its internal $\mathrm{R} \& \mathrm{D}$ structure and the fact that Brazilian industry is positioned on the international scene with an intensive strategy to scale and/or depend on providers.

\section{Final considerations}

This study advanced the discussion of the modelling of organizations' ABIN by proposing a multi-level structured model through latent variable analysis and in an autoregressive manner.

The prospection of the model was based on real information on investments in the innovation process from a broad base of Brazilian companies. However, the study presents the conjectural limitation of the country regarding the heterogeneity of the companies, a fact that complicates a statistical analysis of all of the information gathered. It is 


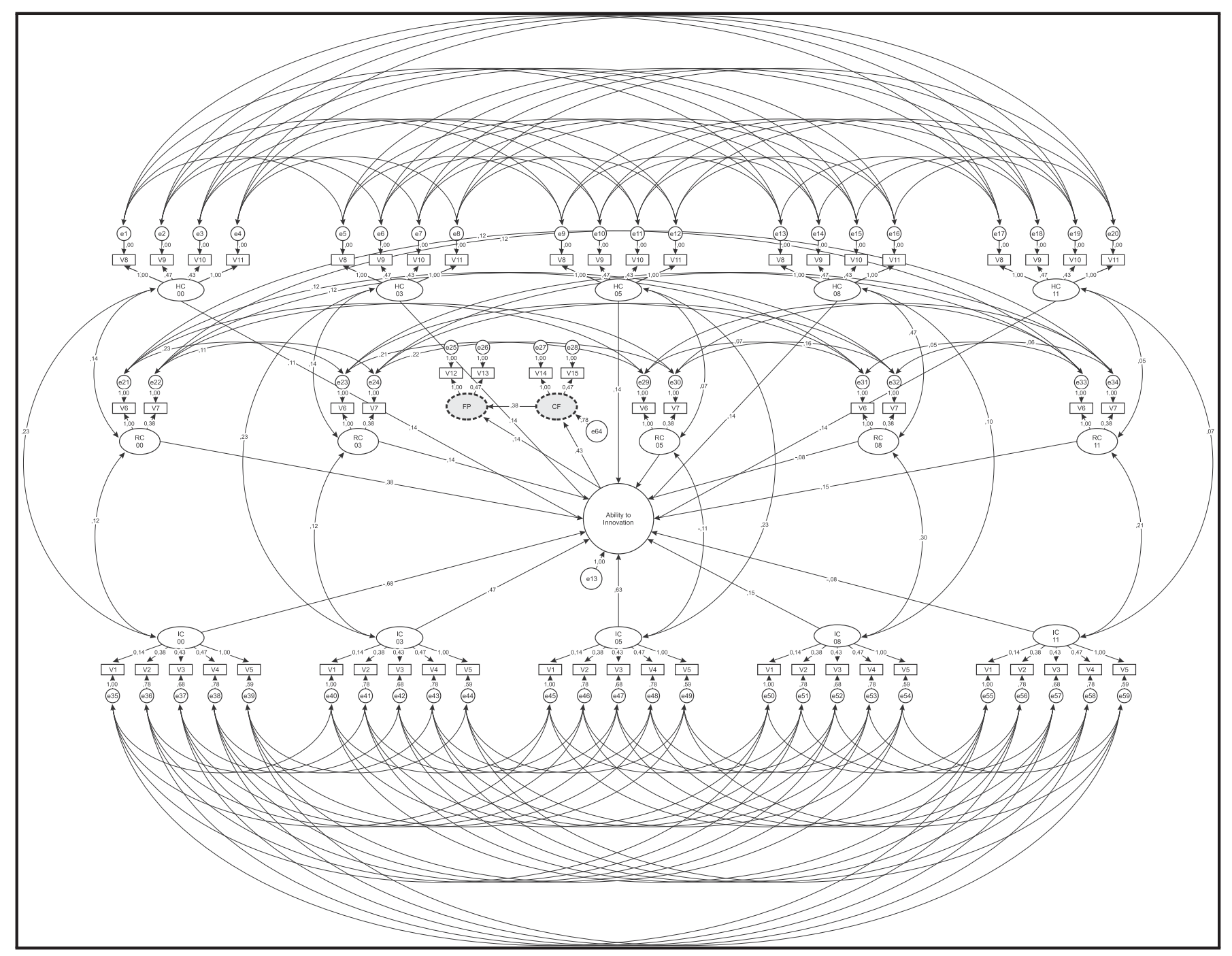

Fig. 3. Innovation management model with trajectory without the autoregressive process.

emphasized that this limitation is a fact that does not occur in most studies on structural equation modelling that use a scale score obtained through a questionnaire.

The access to a data set that includes several in different periods allowed the analysis of relationships between innovation and performance along time. By using longitudinal SEM, we could study complex and latent constructs. However, the study has some limitations. Endogeneity problems due to omitted variables and simultaneous causality can impact results. For instance, other variables can influence performance as well as performance itself can influence the availability of resources related to innovation. Using variables in different periods can reduce endogeneity issues, but not eliminate them. Further studies could explore panel data regressions using instrumental variables to take into account omitted variables.

Regardless of the limitations of the proposed empirical model, it was possible to validate more clearly a framework for the establishment of the ABIN based on the following types of capital: human, internal, and relational. However, the results show that these capitals are not isolated features but rather are investments that are significantly correlated and that congregate tangible and intangible assets. Thus, it is noted that the assumption of the stratified analysis of these resources in financial performance will be limited. It was also found that the cumulative process of innovation occurs in a combined mode over the course of time, not necessarily in a linear fashion.

Public policies that promote innovation are important for the growth of IC and RC, but in the Brazil case, maintaining the participation of researchers in companies and in numbers lower than those in developed countries can contribute to the absence of a greater ABIN, given that researchers drive companies towards technological paradigms.

Environmental conditions, particularly the 2008/2009 crisis, have affected the investments of Brazilian companies in innovation, and this situation requires care by the public entity to ensure the existence of a financial flow for innovation processes because future recovery may require a new learning curve, depending on the speed at which innovation and technological standards are changed.

In this context, there are also the managerial implications of this study, with the following standing out:

i The management of innovation should include an integrated structure of internal and external sources aimed at the ABIN and a structure of researchers oriented towards innovation, which contributes to the company's strategy; and

ii Innovation and, in effect, the generation of results are a cumulative process of knowledge and therefore must be preserved in the business model, aiming at the generation of competitive advantage. Thus, there is no ABIN with specific projects or only specific management practices.

Our study may have some implications for public policies. For 
Table 7

Results of the model with the trajectory of the ABIN latent variable.

\begin{tabular}{|c|c|c|}
\hline Variables & Variables & Coefficients \\
\hline ABIN & IC_03 & $0.355^{k * 2 \times x}$ \\
\hline ABIN & IC_05 & $0.324^{* 2 \times * *}$ \\
\hline ABIN & IC_08 & 0.085 \\
\hline ABIN & HC_03 & $0.103^{k \neq * x}$ \\
\hline ABIN & HC_05 & $0.103^{k x / k}$ \\
\hline ABIN & HC_08 & $0.103^{* \ldots * *}$ \\
\hline ABIN & IC_11 & -0.062 \\
\hline ABIN & HC_11 & $0.103^{k * 2 \times x}$ \\
\hline ABIN & HC_0O & $0.103^{k+k * x}$ \\
\hline ABIN & IC_00 & -0.062 \\
\hline ABIN & RC_00 & $0.284^{k \text { ki*x }}$ \\
\hline ABIN & RC_03 & $0.085^{\text {*⿻*t }}$ \\
\hline ABIN & RC_05 & $0.085^{* * * * x}$ \\
\hline ABIN & RC_08 & -0.062 \\
\hline ABIN & RC_11 & 0.031 \\
\hline CG & ABIN & $0.540^{* \ldots * *}$ \\
\hline Performance & ABIN & $0.351^{k \times * *}$ \\
\hline Performance & CG & 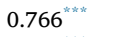 \\
\hline IP_03 & IC_03 & $0.792^{k \ldots * x}$ \\
\hline ITI_03 & IC_03 & $0.470^{\ldots \times * * x}$ \\
\hline TR_03 & IC_03 & $0.462^{* * * *}$ \\
\hline AME_03 & IC_03 & $0.393^{\text {knth }}$ \\
\hline IRD_03 & IC_03 & $0.136^{\text {kntwk }}$ \\
\hline IP_05 & IC_05 & $0.707^{* * * *}$ \\
\hline ITI_05 & IC_05 & $0.521^{* * * *}$ \\
\hline TR_05 & IC_05 & $0.437^{\text {*⿻心㇒t }}$ \\
\hline AME_05 & IC_05 & $0.416^{\text {*n*k* }}$ \\
\hline IRD_05 & IC_05 & $0.153^{* * * *}$ \\
\hline IP_08 & IC_08 & $0.610^{\text {k玄*t}}$ \\
\hline ITI_08 & IC_08 & $0.425^{* \star * * x}$ \\
\hline TR_08 & IC_08 & $0.350^{\text {k*****t* }}$ \\
\hline AME_08 & IC_08 & $0.332^{k \cdots * x}$ \\
\hline IRD_08 & IC_08 & $0.119^{* \ldots * x}$ \\
\hline PHD_03 & HC_03 & $0.792^{* \ldots * x}$ \\
\hline MA_03 & $\mathrm{HC}_{-} \mathrm{O} 3$ & $0.470^{\text {***k }}$ \\
\hline BACH_03 & HC_03 & $0.462^{\text {k市 }}$ \\
\hline TEC_0̄3 & HC_03 & $0.393^{k \ldots k x}$ \\
\hline PHD_05 & HC_05 & 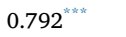 \\
\hline MA_05 & HC_05 & 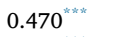 \\
\hline BACH_05 & HC_05 & $0.462^{k \cdots * x}$ \\
\hline TEC_05 & HC_05 & $0.393^{\text {*n*kx }}$ \\
\hline PHD_08 & HC_08 & $0.792^{k \times k x}$ \\
\hline MA_08 & HC_08 & $0.470^{\text {kn*kx}}$ \\
\hline BACH_08 & HC_08 & $0.462^{k * * * x}$ \\
\hline TEC_08 & HC_08 & $0.393^{\text {*⿻xk }}$ \\
\hline IP_11 & IC_11 & $0.792^{* * * *}$ \\
\hline ITI_11 & IC_11 & $0.470^{k * 2 \times x+x}$ \\
\hline TR_11 & IC_11 & $0.462^{k \ldots+k x}$ \\
\hline AME_11 & IC_11 & $0.393^{\text {k.*.**t* }}$ \\
\hline IRD_11 & IC_11 & $0.136^{\text {*****}}$ \\
\hline PHD_11 & HC_11 & $0.792^{\text {k*nk }}$ \\
\hline MA_11 & HC_11 & $0.470^{* \ldots * * x}$ \\
\hline BAC̄H_11 & HC_11 & $0.462^{* \ldots * x}$ \\
\hline TEC_11 & HC_11 & $0.393^{k+\infty x+x}$ \\
\hline PHD_00 & HC_0O & $0.792^{* * * *}$ \\
\hline MA_00 & HC_0O & $0.470^{* * * *}$ \\
\hline BAC̄H_00 & HC_OO & $0.462^{k \cdots *}$ \\
\hline TEC_00 & HC_0O & $0.393^{* * * *}$ \\
\hline IP_00 & IC_00 & $0.792^{* * * * x}$ \\
\hline ITI_00 & IC_00 & $0.470^{* \ldots * x}$ \\
\hline TR_00 & IC_00 & $0.462^{\text {k.*k* }}$ \\
\hline MA__00 & IC_00 & $0.393^{\text {*knkt }}$ \\
\hline IRD_00 & IC_00 & $0.136^{\text {k*****}}$ \\
\hline PDExt_00 & $\mathrm{RC}_{-} 00$ & 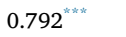 \\
\hline AOK_00 & RC_00 & $0.470^{k * 2 \times x+x}$ \\
\hline ERD_03 & RC_03 & 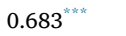 \\
\hline AOK_03 & RC_03 & $0.333^{* * * *}$ \\
\hline ERD_08 & RC_08 & 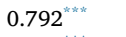 \\
\hline AOK_08 & RC_08 & $0.470^{\text {k**kx }}$ \\
\hline ERD_05 & RC_05 & $0.683^{\text {k.m*k }}$ \\
\hline AOK_05 & RC_05 & $0.333^{* \ldots * x}$ \\
\hline ERD_11 & RC_11 & $0.272^{* \ldots * x}$ \\
\hline AOK_11 & RC_11 & $0.102^{\text {k****}}$ \\
\hline ROA_11 & Performance & $0.458^{* * * *}$ \\
\hline
\end{tabular}

Table 7 (continued)

\begin{tabular}{lll}
\hline Variables & Variables & Coefficients \\
\hline GA_11 & Performance & $0.300^{* * * * *}$ \\
ROS_11 & CG & $0.724^{* * * * *}$ \\
EBTIDAM_11 & CG & $0.539^{* * * * *}$ \\
\hline
\end{tabular}

*** Significance lesser than $1 \%$.

instance, government could encourage private investment in innovations by relaxing trade barriers, guaranteeing stability in credit lines for innovation, and fostering the development of capital markets that finance innovation projects. In addition, government funding to start-ups and innovative companies should be accompanied by the development of an infrastructure that could allow for a more efficient interaction between relational and intellectual capital. Regulatory changes in the relationship between public universities and the private sector should allow greater integration of academic researchers and business entrepreneurs. Although some initiatives regarding business incubators and science parks in Brazil aim to promote a stronger interaction within the triple helix framework, interestingly, most professors at public universities are not allowed to directly participate in or manage private business.

The limitations of this study include the size and access policies of the research data. Regarding the database, due to constraints in the availability of data from industries with few companies, the study could not generate sector-specific results. A sectorial assessment would greatly contribute to the breakdown of the results, given the heterogeneity of the different segments in Brazil.

The inclusion of new companies in the model, or even the analysis of transversal samples, shows that new observations in the PINTEC/PIA will possibly contribute to a better analysis of the model adjustments. In addition, exploring the establishment of the ability to innovate continues to be a frontier field for the better definition and taxonomies of the strategies used by companies and sectors.

\section{References}

Atalay, M., Anafarta, N., Sarvan, F., 2013. The relationship between innovation and firm performance: an empirical evidence from Turkish automotive supplier industry. Procedia. Soc. Behav. Sci. 75 (1), 226-235 apr.

Audigier, V., Husson, F., Josse, J., 2014. A principal component method to impute missing values for mixed data. ADAC 10 (1), 5-26 dec.

Bartoloni, E., Baussola, M., 2017. Driving business performance: innovation complementarities and persistence patterns. Ind. Innov. 1-21. http://dx.doi.org/10. 1080/13662716.2017.1327843. jun.

Baumann, J., Kritikos, A.S., 2016. The link between $r$ \& d, innovation and productivity: are micro firms different? Res. Policy 45 (6), 1263-1274. http://dx.doi.org/10.1016/ j.respol.2016.03.008. jul.

Bernardo, M., 2014. Integration of management systems as an innovation: a proposal for a new model. J. Clean. Prod. 82 (1), 132-142 nov.

Bessant, J., 2008. Dealing with discontinuous innovation: the European experience. Int. J. Technol. Manag. 42 (1/2), 36.

Bollen, K.A., Curran, P.J., 2004. Autoregressive latent trajectory (ALT) models a synthesis of two traditions. Sociol. Methods Res. 32 (3), 336-383 feb.

Bäck, I., Kohtamäki, M., 2015. Boundaries of $r$ \& d collaboration. Technovation 45-46, 15-28. http://dx.doi.org/10.1016/j.technovation.2015.07.002. nov.

Cammarano, A., Michelino, F., Lamberti, E., Caputo, M., 2017. Accumulated stock of knowledge and current search practices: the impact on patent quality. Technol. Forecast. Soc. Chang. 120, 204-222. http://dx.doi.org/10.1016/j.techfore.2016.12. 019. jul.

Cantwell, J., Fai, F., 1999. Firms as the source of innovation and growth: the evolution of technological competence. J. Evol. Econ. 9 (3), 331-366 aug.

Castellacci, F., 2008. Technological paradigms, regimes and trajectories: manufacturing and service industries in a new taxonomy of sectoral patterns of innovation. Res. Policy 37 (6-7), 978-994. http://dx.doi.org/10.1016/j.respol.2008.03.011. jul.

Castellacci, F., Natera, J.M., 2016. Innovation, absorptive capacity and growth heterogeneity: development paths in latin America 1970-2010. Struct. Chang. Econ. Dyn. 37, 27-42. http://dx.doi.org/10.1016/j.strueco.2015.11.002. jun.

Cimoli, M., Dosi, G., 1995. Technological paradigms, patterns of learning and development: an introductory roadmap. J. Evol. Econ. 5 (3), 243-268 sep.

Colombo, M.G., Rabbiosi, L., 2014. Technological similarity, post-acquisition r \& d reorganization, and innovation performance in horizontal acquisitions. Res. Policy 43 (6), 1039-1054. http://dx.doi.org/10.1016/j.respol.2014.01.013. jul.

Cozzarin, B.P., 2004. Innovation quality and manufacturing firms performance in Canada. 
Econ. Innov. New Technol. 13 (3), 199-216 apr.

Crossan, M.M., Apaydin, M., 2009. A multi-dimensional framework of organizational innovation: a systematic review of the literature. J. Manag. Stud. 47 (6), 1154-1191 sep.

Cruz-González, J., López-Sáez, P., Navas-López, J.E., Delgado-Verde, M., 2015. Open search strategies and firm performance: the different moderating role of technological environmental dynamism. Technovation 35, 32-45. http://dx.doi.org/10.1016/ j.technovation.2014.09.001. jan.

Cyrino, A.B., Parente, R., Dunlap, D., de Góes, B.B., 2017. A critical assessment of Brazilian manufacturing competitiveness in foreign markets. Compet. Rev. 27 (3), 253-274. http://dx.doi.org/10.1108/cr-08-2016-0046. may.

Damanpour, F., Walker, R.M., Avellaneda, C.N., 2009. Combinative effects of innovation types and organizational performance: a longitudinal study of service organizations. J. Manag. Stud. 46 (4), 650-675 jun.

de Guimarães, J.C.F., Severo, E.A., Dorion, E.C.H., Coallier, F., Olea, P.M., 2016. The use of organisational resources for product innovation and organisational performance: a survey of the Brazilian furniture industry. Int. J. Prod. Econ. 180, 135-147. http://dx. doi.org/10.1016/j.ijpe.2016.07.018. oct.

de Moraes Silva, D.R., Furtado, A.T., Vonortas, N.S., 2017. University-industry r \& d cooperation in Brazil: a sectoral approach. J. Technol. Transf. http://dx.doi.org/10. 1007/s10961-017-9566-Z. mar.

Delsing, M.J.M.H., Oud, J.H.L., 2008. Analyzing reciprocal relationships by means of the continuous-time autoregressive latent trajectory model. Statistica Neerlandica 62 (1), $58-82$ jan.

Dewangan, V., Godse, M., 2014. Towards a holistic enterprise innovation performance measurement system. Technovation 34 (9), 536-545 sep.

Dray, S., 2008. On the number of principal components: a test of dimensionality based on measurements of similarity between matrices. Comput. Stat. Data Anal. 52 (4), 2228-2237 jan.

Figueiredo, P.N., 2010. Discontinuous innovation capability accumulation in latecomer natural resource-processing firms. Technol. Forecast. Soc. Chang. 77 (7), 1090-1108 sep.

Forés, B., Camisón, C., 2016. Does incremental and radical innovation performance depend on different types of knowledge accumulation capabilities and organizational size? J. Bus. Res. 69 (2), 831-848 feb.

François, J., Favre, F., Negassi, S., 2002. Competence and organization: two drivers of innovation. Econ. Innov. New Technol. 11 (3), 249-270 jan.

Frank, A.G., Cortimiglia, M.N., Ribeiro, J.L.D., de Oliveira, L.S., 2016. The effect of innovation activities on innovation outputs in the Brazilian industry: market-orientation vs. technology-acquisition strategies. Res. Policy 45 (3), 577-592. http://dx.doi. org/10.1016/j.respol.2015.11.011. apr.

Freeman, C., Soete, L., 1997. The Economics of Industrial Innovation. Pinter, London.

Geiser, C., Bishop, J., Lockhart, G., Shiffman, S., Grenard, J.L., 2013. Analyzing latent state-trait and multiple-indicator latent growth curve models as multilevel structural equation models. Front. Psychol. 4 (1).

Gunday, G., Ulusoy, G., Kilic, K., Alpkan, L., 2011. Effects of innovation types on firm performance. Int. J. Prod. Econ. 133 (2), 662-676. http://dx.doi.org/10.1016/j.ijpe. 2011.05.014. oct.

Hashi, I., Stojčić, N., 2013. The impact of innovation activities on firm performance using a multi-stage model: evidence from the community innovation survey 4. Res. Policy 42 (2), 353-366 mar.

Hatzikian, Y., 2013. Exploring the link between innovation and firm performance. J. Knowl. Econ. 6 (4), 749-768 mar.

Hinloopen, J., 2003. Innovation performance across Europe. Econ. Innov. New Technol. 12 (2), 145-161 mar.

Howell, A., 2016. Firm $\mathrm{r} \& \mathrm{~d}$, innovation and easing financial constraints in China: does corporate tax reform matter? Res. Policy 45 (10), 1996-2007. http://dx.doi.org/10. 1016/j.respol.2016.07.002. dec.

Hu, B., 2014. Linking business models with technological innovation performance through organizational learning. Eur. Manag. J. 32 (4), 587-595 aug.

Hu, M.-C., 2008. Knowledge flows and innovation capability: the patenting trajectory of Taiwan thin film transistor-liquid crystal display industry. Technol. Forecast. Soc. Chang. 75 (9), 1423-1438 nov.

Hung, K.-P., Chou, C., 2013. The impact of open innovation on firm performance: the moderating effects of internal $\mathrm{r} \& \mathrm{~d}$ and environmental turbulence. Technovation 33 (10-11), 368-380 oct.

Jackson, S.A., Gopalakrishna-Remani, V., Mishra, R., Napier, R., 2016. Examining the impact of design for environment and the mediating effect of quality management innovation on firm performance. Int. J. Prod. Econ. 173 (1), 142-152 mar.

Jiménez-Jiménez, D., Sanz-Valle, R., 2011. Innovation, organizational learning, and performance. J. Bus. Res. 64 (4), 408-417 apr.

Kash, D.E., Rycroft, R., 2002. Emerging patterns of complex technological innovation. Technol. Forecast. Soc. Chang. 69 (6), 581-606 jul.

Kim, B., Kim, E., Miller, D.J., Mahoney, J.T., 2016. The impact of the timing of patents on innovation performance. Res. Policy 45 (4), 914-928 may.

Kirner, E., Kinkel, S., Jaeger, A., 2009. Innovation paths and the innovation performance of low-technology firms-an empirical analysis of German industry. Res. Policy 38 (3), 447-458. http://dx.doi.org/10.1016/j.respol.2008.10.011. apr.

Kleinschmidt, E., 1991. The impact of product innovativeness on performance. J. Prod. Innov. Manag. 8 (4), 240-251 dec.

Klingenberg, B., Timberlake, R., Geurts, T.G., Brown, R.J., 2013. The relationship of operational innovation and financial performance-a critical perspective. Int. J. Prod. Econ. 142 (2), 317-323 apr.

Kostopoulos, K., Papalexandris, A., Papachroni, M., Ioannou, G., 2011. Absorptive capacity, innovation, and financial performance. J. Bus. Res. 64 (12), 1335-1343 dec.

Lancker, J.V., Mondelaers, K., Wauters, E., Huylenbroeck, G.V., 2016. The organizational innovation system: a systemic framework for radical innovation at the organizational level. Technovation 52-53, 40-50. http://dx.doi.org/10.1016/j.technovation.2015. 11.008. jun.

Lewin, A.Y., Massini, S., Peeters, C., 2011. Microfoundations of internal and external absorptive capacity routines. Organ. Sci. 22 (1), 81-98. http://dx.doi.org/10.1287/ orsc.1100.0525. feb.

Liao, T.-S., Rice, J., 2010. Innovation investments, market engagement and financial performance: a study among australian manufacturing SMEs. Res. Policy 39 (1), 117-125 feb.

Lichtenthaler, U., 2016. Absorptive capacity and firm performance: an integrative framework of benefits and downsides. Tech. Anal. Strat. Manag. 28 (6), 664-676. http://dx.doi.org/10.1080/09537325.2015.1131258. jan.

Linton, J.D., Walsh, S.T., 2004. Integrating innovation and learning curve theory: an enabler for moving nanotechnologies and other emerging process technologies into production. R D Manag. 34 (5), 517-526. http://dx.doi.org/10.1111/j.1467-9310. 2004.00359.x. nov.

Little, T.D., 2013. Longitudinal Structural Equation Modeling. The Guilford Press, New York.

Lööf, H., Heshmati, A., 2006. On the relationship between innovation and performance: a sensitivity analysis. Econ. Innov. New Technol. 15 (4-5), 317-344 jun.

Luo, B.N., Lui, S.S., Kim, Y., 2017. Revisiting the relationship between knowledge search breadth and firm innovation. Manag. Decis. 55 (1), 2-14. http://dx.doi.org/10.1108/ md-07-2015-0327. feb.

Lööf, H., Heshmati, A., 2002. Knowledge capital and performance heterogeneity: Int. J. Prod. Econ. 76 (1), 61-85. http://dx.doi.org/10.1016/s0925-5273(01)00147-5. mar.

Maslach, D., 2015. Change and persistence with failed technological innovation. Strateg. Manag. J. 37 (4), 714-723. http://dx.doi.org/10.1002/smj.2358. jan.

MCTI, 2016. Consolidated indicators. In: Tech. rep. Brazilian Ministry of Science, Technology, Innovations and Communications. www.mct.gov.br/index.php/ content/view/2068.html.

Olaru, D., Purchase, S., 2015. Innovation network trajectories: the role of time and history. J. Bus. Ind. Mark. 30 (3/4), 342-353 may.

Paunov, C., 2012. The global crisis and firms' investments in innovation. Res. Policy 41 (1), 24-35 feb.

Pavitt, K., 1984. Sectoral patterns of technical change: towards a taxonomy and a theory. Res. Policy 13 (6), 343-373 dec.

Prajogo, D.I., 2016. The strategic fit between innovation strategies and business environment in delivering business performance. Int. J. Prod. Econ. 171, 241-249. http://dx.doi.org/10.1016/j.ijpe.2015.07.037. jan.

Rangus, K., Slavec, A., 2017. The interplay of decentralization, employee involvement and absorptive capacity on firms innovation and business performance. Technol. Forecast. Soc. Chang. 120, 195-203. http://dx.doi.org/10.1016/j.techfore.2016.12. 017. jul.

Ritala, P., Olander, H., Michailova, S., Husted, K., 2015. Knowledge sharing, knowledge leaking and relative innovation performance: an empirical study. Technovation 35 , 22-31. http://dx.doi.org/10.1016/j.technovation.2014.07.011. jan.

Rousseau, M.B., Mathias, B.D., Madden, L.T., Crook, T.R., 2016. Innovation, firm performance, and appropriation: a meta-analysis. Int. J. Innov. Manag. 20 (3), 1650033 apr.

Ryu, H.-S., Lee, J.-N., 2016. Innovation patterns and their effects on firm performance. Serv. Ind. J. 36 (3-4), 81-101 mar.

Samara, E., Georgiadis, P., Bakouros, I., 2012. The impact of innovation policies on the performance of national innovation systems: a system dynamics analysis. Technovation 32 (11), 624-638 nov.

Santos, D.F.L., Basso, L.F.C., Kimura, H., Kayo, E.K., 2014. Innovation efforts and performances of Brazilian firms. J. Bus. Res. 67 (4), 527-535 apr.

Shafique, M., 2012. Thinking inside the box? Intellectual structure of the knowledge base of innovation research (1988-2008). Strateg. Manag. J. 34 (1), 62-93 jul.

Silverberg, G., Verspagen, B., 2005. A percolation model of innovation in complex technology spaces. J. Econ. Dyn. Control. 29 (1-2), 225-244 jan.

Solow, R.M., 1957. Technical change and the aggregate production function. Rev. Econ. Stat. 39 (3), 312-320.

Stefan, I., Bengtsson, L., 2017. Unravelling appropriability mechanisms and openness depth effects on firm performance across stages in the innovation process. Technol. Forecast. Soc. Chang. 120, 252-260. http://dx.doi.org/10.1016/j.techfore.2017.03. 014. jul.

Sundbo, J., Gallouj, F., 2000. Innovation as a loosely coupled system in services. Int. J. Serv. Technol. Manag. 1 (1), 15

Tavassoli, S., Karlsson, C., 2015. Persistence of various types of innovation analyzed and explained. Res. Policy 44 (10), 1887-1901. http://dx.doi.org/10.1016/j.respol.2015. 06.001. dec.

Teece, D.J., 2010. Business models, business strategy and innovation. Long Range Plann. 43 (2-3), 172-194 apr.

Tsai, W., 2001. Knowledge transfer in intraorganizatiional networks: effect of network position and absorptive capacity on business unit innovation and performance. Acad. Manage. J. 44 (5), 996-1004. http://dx.doi.org/10.2307/3069443. oct.

UNDP, 2013. Human development report 2013. In: Tech. rep. United Nations Development Programme, Washington, DC Communications Developmen Incorporated.

Urgal, B., Quintás, M.Á., Tomé, R.A., 2011. Conocimiento tecnológico, capacidad de innovación y desempeño innovador: el rol moderador del ambiente interno de la empresa. Cuadernos de Economí,a y Dirección de la Empresa 14 (1), 53-66 jan.

Velu, C., 2015. Business model innovation and third-party alliance on the survival of new firms. Technovation 35, 1-11. http://dx.doi.org/10.1016/j.technovation.2014.09. 007. jan.

Wang, C.-H., Chang, C.-H., Shen, G.C., 2015. The effect of inbound open innovation on 
firm performance: evidence from high-tech industry. Technol. Forecast. Soc. Chang. 99, 222-230. http://dx.doi.org/10.1016/j.techfore.2015.07.006. oct.

Wang, Y., Li, J., Furman, J.L., 2017. Firm performance and state innovation funding: evidence from China's innofund program. Res. Policy 46 (6), 1142-1161. http://dx. doi.org/10.1016/j.respol.2017.05.001. jul.

Wang, Y., Zhou, Z., Li-Ying, J., 2012. The impact of licensed-knowledge attributes on the innovation performance of licensee firms: evidence from the chinese electronic industry. J. Technol. Transf. 38 (5), 699-715 may.

Wang, Z., Wang, N., 2012. Knowledge sharing, innovation and firm performance. Expert Syst. Appl. 39 (10), 8899-8908 aug.

Weber, K.M., Schaper-Rinkel, P., 2017. European sectoral innovation foresight: identifying emerging cross-sectoral patterns and policy issues. Technol. Forecast. Soc. Chang. 115, 240-250. http://dx.doi.org/10.1016/j.techfore.2016.09.007. feb.

WEF, 2015. The global competitiveness report 2015-2016. In: Tech. rep. World Economic Forum, Geneva.

WIPO, C.U.I., 2015. The global innovation index 2015: Effective innovation policies for development. In: Tech. rep. World Intellectual Property Organization.

WTO, 2015. International trade statistics 2015. In: Tech. rep. World Trade Organization, Geneva.

Wu, J., Wang, C., Hong, J., Piperopoulos, P., Zhuo, S., 2016. Internationalization and innovation performance of emerging market enterprises: the role of host-country institutional development. J. World Bus. 51 (2), 251-263 feb.

Xie, X., Huo, J., Qi, G., Zhu, K.X., 2016. Green process innovation and financial performance in emerging economies: moderating effects of absorptive capacity and green subsidies. IEEE Trans. Eng. Manag. 63 (1), 101-112 feb.

Ye, J., Hao, B., Patel, P.C., 2016. Orchestrating heterogeneous knowledge: the effects of internal and external knowledge heterogeneity on innovation performance. IEEE Trans. Eng. Manag. 63 (2), 165-176 may.

Yuan, K.-H., Bentler, P.M., 2007. Multilevel covariance structure analysis by fitting multiple single level models. Sociol. Methodol. 37 (1), 53-82 dec.
Dr. David Ferreira Lopes Santos is an assistant professor at the Department of Economics, Management and Education at São Paulo State University. He holds PhD degree in Administration from the Mackenzie Presbyterian University. He is recently conducting additional research lines related to firms' innovation dynamic and innovation habitats. His research interests focus on innovation, eco-innovation and business performance assessment. Since May 2015 he is the coordinator of the postgraduate program in Administration at São Paulo State University. He has published in a range of academic journals including Journal of Business Research, Brazilian Journal of Science and Technology, Regional and Sectoral Economic Studies and International Journal of Business and Emerging Markets.

Dr. Leonardo Fernando Cruz Basso was born in Araraquara (Brazil) and graduated in Mechanical Engineering from the Technological Institute of Aeronautics (ITA- Sao Jose dos Campos, Brazil-1974), MA and PhD in Economics - New School for Social Research (New York-1979-1984) He attended a post-doctoral program at the University of Bielefeld (Germany). Full professor at the Department of Economics- Mackenzie Presbyterian University (São Paulo, Brazil). Researcher of the National Council for Scientific and Technological Development (CNPq/Brazil), with experience in economics and business, with emphasis in the following areas: value creation, open economy macroeconomics, valuation, innovation, intangible assets, exchange rate and intellectual capital.

Dr. Herbert Kimura is a full professor at the Department of Business Management at the University of Brasilia and researcher of the National Council for Scientific and Technological Development (CNPq/Brazil). He holds PhD degrees in Statistics and Business from the University of Sao Paulo. His research interests focus on innovation, performance assessment and risk management. He has published in a range of academic journals including Journal of Business Research, Journal of Banking and Finance, Journal of Financial Stability, Numerical Linear Algebra with Application and International Review of Financial Analysis. Dr. Kimura was the manager of the University of Brasilia's Science Park and Incubator Program from August/2013 to January/2017. 